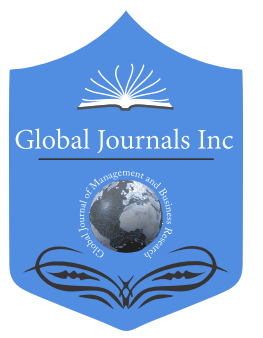

\title{
Earnings Management in Light of the Shift to International Financial Reporting Standards (IFRS): An Exploratory Study on Saudi Corporations
}

\author{
By Dr. Fahad Sulaiman M Alnafea
}

Qassim University

Abstract- This study aims to study the Earnings management in light of the shift to International Financial Reporting Standards (IFRS) through a field study, which has occurred in Saudi jointstock companies. Through research, I achieved several results, such as: That there is change expected to happen in Earnings management in light of the shift to International Financial Reporting Standards (IFRS) via: Manipulating both the expenditure and revenue in the income statement, The manipulation of the accounts of Balance Sheet Statement, The manipulation of cash flows statement, as well as through the manipulation of reports of the changes in equity statement. The accountants in Saudi Corporations are concerned to shift to IFRS, expecting that the Earnings management is going on; thus, the IFRS had implemented.

Keywords: international financial reporting standards (IFRS), earnings management, income smoothing.

GJMBR-C Classification: JEL Code: F30

Strictly as per the compliance and regulations of:

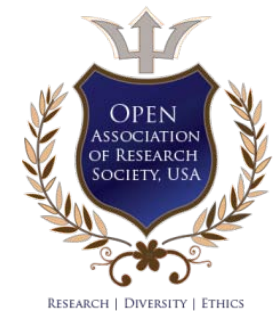

(c) 2020. Dr. Fahad Sulaiman M Alnafea. This is a research/review paper, distributed under the terms of the Creative Commons Attribution-Noncommercial 3.0 Unported License http://creativecommons.org/licenses/by-nc/3.0/), permitting all non-commercial use, distribution, and reproduction in any medium, provided the original work is properly cited. 


\title{
Earnings Management in Light of the Shift to International Financial Reporting Standards (IFRS): An Exploratory Study on Saudi Corporations
}

\author{
Dr. Fahad Sulaiman M Alnafea
}

Abstract-This study aims to study the Earnings management in light of the shift to International Financial Reporting Standards (IFRS) through a field study, which has occurred in Saudi joint-stock companies. Through research, I achieved several results, such as: That there is change expected to happen in Earnings management in light of the shift to International Financial Reporting Standards (IFRS) via: Manipulating both the expenditure and revenue in the income statement, The manipulation of the accounts of Balance Sheet Statement, The manipulation of cash flows statement, as well as through the manipulation of reports of the changes in equity statement. The accountants in Saudi Corporations are concerned to shift to IFRS, expecting that the Earnings management is going on; thus, the IFRS had implemented. On the other hand, they also expect to improve the quality of the accounting information. Based on previous results, the researcher included a set of recommendations such as the need to educate accountants in Saudi listed firms about the importance of the transition to International Financial Reporting Standards (IFRS), and its positive role in reducing the Earnings management and improving the quality of accounting information, the need to work out a partnership between Saudi universities, Saudi Organization of Certified Public Accountants (SOCPA) and Saudi audit firms to study the phenomenon of Earnings management and its methods to work on reducing its existence, and its impact on the quality of accounting information. The need for governmental intervention through the SEC to contribute and labour establish strict laws and regulations, which reduce the Earnings management in companies and increase the transparency and quality of accounting information.

Keywords: international financial reporting standards (IFRS), earnings management, income smoothing.

\section{InTRODUCTION}

$\mathrm{N}$ et profit indicator is substantial to both investors and management, which makes administration seeks to increase earnings to improve the financial position of companies in the stock market or to show its good conduct through accounting procedures, which are known as earnings management. These procedures are some sort of manipulative income to reach a predetermined managerial goal through manipulating the measurement and the external financial report to be compatible with specific workflows

Author: Associate Professor Accounting Department Qassim University. e-mail: fahadsn99@gmail.com and gaining earnings especially for the company or its management.

According to the International Accounting Standards Board (IASB), more than 100 countries have adopted International Financial Reporting Standards (IFRS) (LASB 2009). At present, the Kingdom of Saudi Arabia (KSA) is considering its adaptation too, especially after several events in the Saudi stock market that resulted from the lack of transparency and disclosure of information on the status of financial positions of companies which have not yet reached the limit that the investor hopes. Perhaps developments that took place in the Kingdom with about either the issuance of new influential systems such as the capital market for securities and attracting foreign investment or updating the regulations and regulations such as the corporate system, it's most are companies? Adding to that the increased number of the listed companies, the increased international investments, frequent flow of information, including financial reports via the Internet, and The Kingdom's accession to the World Trade Organization (WTO), all this underscores the importance of taking practical steps to review, modernize and develop everything related to the capital market for securities and the profession of accounting and auditing in the Kingdom because of a major impact in the economy and its dealers of facilities and individuals (Alsalan: 2012) including the accounting standards system. This development of standards will have a role in reducing the earnings management of companies, which, if not taken strict measures, may lead to the collapse of companies and the erosion of capital in addition to the effects on the national economy in general.

Therefore, this research will try to answer the following questions:

1. What is the expected change of earnings management in light of the transition to IFRS?

2. Does switching to IFRS improve the quality of financial reporting?

This research aims to:

1. To show the concept of earnings management and the quality of accounting information. 
2. To show how to measure the earnings management and the quality of accounting information.

3. To show the impact of the shift to international standards on earnings management and the quality of accounting information.

There is no doubt that the unifying of global harmony and conformity in the financial report by increasing the comparability, understanding, and disclosure of accounting information plays a role in raising the accounting information quality, which highlights the importance of this research in two ways:

First: That this research comes at a time when the Kingdom is considering the adoption of international standards for financial reporting, and the SOCPA has taken several measures to ensure a successful transition to the application of these standards. Hence, this research becomes an indicator of the validity or nonvalidity of this transformation.

Second: It represents a practical experience on the extent to which the adoption of these standards affects the quality of accounting information which are provided by accounting systems for Saudi companies after adopting these standards. Also, compliance with these standards by Saudi companies will increase confidence in the data and information contained in its financial statements. This will help make correct decisions by decision makers of all degrees. The Kingdom's entry into the G-20 will also make it a commitment to adopt these criteria (Abdelmawli and Abu Amara, 2012).

\section{ReseArch Assumptions}

The research will examine the following two basic assumptions:

The first basic assumption: There is no expected change in earnings management in light of the transition to IFRS.

First Hypothesis: There is no expected change in earnings management in light of the transition to IFRS by manipulating expenses in the income statement.

Second Hypothesis: There is no expected change in earnings management in light of the transition to IFRS by manipulating revenue in the income statement.

Third Hypothesis: There is no expected change in earnings management in light of the transition to IFRS by manipulating the accounts of the financial position.

Fourth Hypothesis: There is no expected change in earnings management in light of the transition to IFRS by manipulating the cash flow statement.

Fifth Hypothesis: There is no expected change in earnings management in light of the transition to IFRS by manipulating change in statement of equity.

The second basic assumption: There is no statistically significant impact at the level of indication $(a=0.05)$ of the shift in IFRS to improve the quality of accounting information.

The third basic assumption: There is no statistically significant impact at the level of indication $(a=0.05)$ in the expected change in earnings management in light of the transition to IFRSs attributable to the accounting qualification of accountants.

The fourth basic assumption: There is no statistically significant impact at the level of indication $(a=0.05)$ in the expected change in earnings management in light of the transition to IFRSs attributable to the experience of accountants.

\section{ili. Research Theoretical Framework}

\section{a) Previous studies}

Many of the researches dealt with this subject from several angles as follows:

i. Studies on the positive impact of the transformation of international financial reporting standards on earnings management

The study of Guoping Liu, Jerry Sun 2014, examined the positive effect of the optional adoption of IFRS on reducing earnings management, in addition to improving the quality of accounting information in Canadian companies.

And the study of WARES Karim, 2011, demonstrated the impact of the adoption of IFRS and investor protection on profit quality. This study showed that 64 countries around the world had adopted the mandatory adoption of IFRS standards, which increased the value of earnings, especially when there is a protection system for the most investors. The results of this study highlight the importance of protecting the investor from obtaining the quality of financial reports and the need for regulators to design procedures or mechanisms that limit the practice of managing managers' earnings.

The study of Yuang-Lin Chang, and Dr. ChengHwai Liou, 2013, also examined the impact of mandatory adoption of IFRS and the institutional environment on the quality of accounting information. The researchers concluded the result of the apparent improvement in the quality of accounting information after adoption of these standards.

And the study of Yi Lin (Elaine) Chua, Chee Seng Cheong, and Graeme Gould, 2012, examined the impact of compulsory adoption of IFRS on the quality of accounting information, focusing on three issues: managing earnings, recognizing the loss in the right time, and the importance of value. Based on the mandatory application results of these standards for four years, the researchers concluded that the compulsory application of IFRS resulted in better accounting information than under local Australian standards (Australian GAAP). More precisely, 
earnings management has been reduced by earnings smoothing. At the same time immediate recognition of losses is improving after the adoption of IFRS. The value of financial information, especially in non-profit companies, has also improved. These results were contrary to expectations that there is evidence that Australian financial firms are involved in managing earnings after the mandatory adoption of IFRS.

The study of Ying Wang and Michael Campbell, 2012 examined earnings management in China under both GAAP and IFRS. In this study, data from companies listed on the Chinese stock market for the period 1998-2009 had used to compare earnings management indicators before and after IRFS adoption. There has been no evidence that the adoption of IFRS standards will increase or reduce earnings management in Chinese companies.

The study of Lei Cai, Asheq Rahman, and Stephen Centenary, 2006, was on the Effect of the Adoption of International Financial Reporting Standards on earnings management: An International Comparison. Where researchers studied the mandatory adoption of IFRS standards, its impact on the financial report and earnings management. The study was on more than 10,000 companies around the world, during the period of the project from 2003-2006. The result was that earnings management declined significantly in those countries that adopted IFRS. Countries with enforcement measures were also less likely to earnings management.

The study of Stergios Leventis and Panagiotis E. Dimitropoulos Asokan Anandarajan, 2011, on "Loan Loss Provisions, Earnings Management and Capital Management under IFRS: The Case of Commercial Banks in the European Union" examined the impact of the adoption of IFRS on the use of provisions for loan losses in earnings and capital management. The study sample included 91 commercial banks during ten years of study before and after the adoption of IFRS. The study concluded that the level of earnings management in those banks that adopted IFRS standards had reduced by reducing the tendency of managers of commercial banks listed in the European market to earnings management by taking loan loss provisions.

A study by Barth, Landsman, and Lang, 2008 focused on the quality of accounting in 21 countries that adopted IFRS standards from 1994 to 2003. The researchers tested the adoption of IFRS standards on the quality of accounting information, they concluded that the countries that adopted the IFRS standards had better accounting information quality, less manipulation of the earnings of companies, recognition of losses for more than once, and a higher degree of integration between accounting information, prices and returns.

In the study of Wagehofer, 2005, on "The impact of accounting standards on reducing earnings management," the researcher concluded that the existence of more stringent accounting standards has a direct impact on the quality of profitability, which reduces the number of alternative accounting treatments and describes clear and specific rules for these accounting treatments. Some studies also addressed the relationship between IFRS standards and earnings management, and earnings management appears to be less pronounced in those economies with large equity markets for private equity firms.

b) Studies on the negative impact of the transformation of international financial reporting standards on earnings management

The Harris Peter 2012 study found that despite the advantages of IFRS, it limits the earnings management. Vedran Capkun and others, 2012, found that earnings management in companies that adopted IFRS was better than those they did not adopt, which is the opposite of the conclusion of the Stergioua Leventis and others 2013 study.

The study of Liu Guoping and Jerry Sun, 2011, on the effect of mandatory adoption of International Financial Reporting Standards (IFRS) on the quality of earnings in Canadian companies found that the profit of these companies had not yet improved after the adoption of IFRS, for a sample of 487 Canadian companies. On the contrary, the expected absolute receivables value of mining companies increased after the adoption of IFRS. This indicates a decline in earnings after the adoption of IFRS. The researchers concluded that the increase in the quality of profits in the Canadian private sector could not have been traced back to the adoption of IFRS standards.

The study of Akinobu and Kazuyuki Suda, 2005, on earnings management to avoid losses-an applied study from Japan, showed that Japanese companies have already exercised earnings management to reduce and conceal losses. Dividends in Japanese companies indicate that managers in Japanese firms are more likely to engage in earnings management to avoid losses than the managers in the USA firms. The study showed that firms able to manage earnings at a lower cost are more likely to engage in earnings management.

A study conducted by Anwar S. Ahmed, Michael Neel, and Dechum Wang, 2012 examined the effect of compulsory adoption of IFRS on quality accounting by studying a sample of 20 countries in the world. The study showed that the countries that adopted these standards showed an increase in profits smoothing and the report of the aggressive receivables and a decline in recognition of a loss at the right time. These results contradict some of the previous studies that suggest that the adoption of IFRS standards will lead to higher quality accounting. The study was in those companies located in countries with strict 
guidelines. It found that the strict guidelines in these countries was not sufficient to counteract the flexibilities given by the IFRS standards as compared to the local gauge of those countries.

The study of Michael Firth, Demitrius Gounopoulos, and Jannis Pulm, 2013, on the effect of IFRS standards on predicting the earnings management of Australian subscription companies came to the result: at the as a result of the adoption of IFRS standards leads to higher expectations of errors compared to the period in which GAAP standards were in place. The size of the forecast errors is related to the size of the establishment and the industry branch to which it belongs.

The study of Guoping Liu and Jerry Sun, 2013, was on the effect of compulsory adoption of IFRS on the quality of earnings of Canadian companies. In this study, a comparison is made for the quality of the profits that were measured by expected absolute receivables, small positive earnings, and big positive profits before and after adopting IFRS standards for a sample of 487 companies. It found that the quality of profits did not improve after the adaptation of IFRS. On the contrary, the expected absolute receivables of the mining companies increased after the adaptability of IFRS.

The study of Thomas Jeanjeana and Herve Stlowya, 2008 was on the mandatory application of IFRS and its impact on revenue quality and earnings management. The earnings management has not decreased after adopting IFRS standards, but on the contrary, it rose in France after the adoption of the new standards, while it remained the same in Britain and Australia. The study found that IFRS was unsuccessful in reducing earnings management in companies that adopted these standards.

The study of Goncharov and Zimmermann, 2007 studied earnings management in the German companies using different accounting standards: German accounting standards, the USA accounting standards, and IFRS standards. The study showed that companies that applied US accounting standards (US GAAP) had low levels of earnings management. While the companies that adopted the German accounting standards as well as, international accounting standards (G GAAP, IFRS) were equally earnings management. They concluded that different accounting processes would have an impact on earnings management levels.

c) Studies on the different impacts of IFRS adoption from several aspects

Leuz, 2003 studied the impact of IFRS standards on capital cost (Daske, 2006, Lambert, Leuz and Verrecchia, 2007), and the contribution of IFRS standards to improve market liquidity (Daske, Hail, Leuz and Berdi, 2008). Clements, Neil and Stovall, 2010 analyzed the cultural diversity and size of the country to determine and relate to the shift to IFRS standards and the reluctance of others. The result was that cultural differences did not appear to play a role in that transformation, while the larger the size of the country, the less there is a desire to switch to the IFRS standards. This is because these countries have developed their accounting reporting systems well and are reluctant to bear the additional costs of switching to the IFRS standards.

In an analytic study of Peng and Smith, 2010, the authors analyzed the process of transforming China from GAAP standards to IFRS standards. They concluded that significant steps had taken towards China's transformation in the process of issuing local Chinese standards, which took place in four stages: 1992, 1998, 2001 and 2006. They made a table showing the transformation process during each of the four phases. The percentage of transformation varied from $20 \%$ in 1992 to $77 \%$ in 2006 . Leuz devised a way to measure the level of earnings management in companies that had implemented on 1/1/2007.

Ying Wang and Michael Campbell, 2012, also used the method in which earnings management were measured, which was invented by Leuz. Leuz and Daske et al., 2008 looked at the economic outcome of applying IFRS standards in the companies. They concluded that the liquidity of the market increased at the beginning of stratifying these standards. They also noted a drop in the cost of capital and an increase in equity valuations. The effects possibly occurred before the official date of adoption of the IFRS standards. However, these effects occur in those countries that have incentives to act transparently and have powerful enforcement of laws. The study of Patricia et al. 2011, presented a new approach to the discovery of earnings management based on interest in the quality of revenues, not in abundance the quality here means the viability of such revenues for collection.

In Souichi Matsuura, 2008 study on real earnings management and accountant earnings management for earnings smoothing in Japan, the researcher proposed a division of earnings management to actual earnings management and accounting earnings management. The estimated cash flows were used as a variable parameter to measure the earnings management; the estimated receivables had also used as a basis for calculating the accounting earnings management. The researcher concluded that there is a smooth relationship between the real earnings management and accounting earnings management, and managers also use both true earnings management and accounting earnings management to set earnings smoothing.

Through my review, the researcher can reach the following concepts: 


\section{d) Income Smoothing}

Several researchers have dealt with the concept of income smoothing for study and analysis. The Fudenberg and Tirole, 1955 study referred to the idea of income smoothing as all the methods and processes used by management in business organizations, to reduce income to reduce the degree of risk in the Company's investments. Ashari et al.1994 also defined income smoothing as a deliberate act by the management of the enterprise for reducing income fluctuations using specific accounting tools. Also, the Mathews, 1991 study referred to the income smoothing as a set of mechanisms in which earnings are reduced in periods of significant increase and increased in periods when they fall significantly. Belkaoui, 2000 sees income smoothing as "a deliberate settlement of the declared income to reach the desired level or direction, and it expresses the administration's desire to reduce the abnormal deviation in income to the extent possible or permissible under the accepted principles of accounting and management. "Several researchers, such as Trueman, Dahran, and Van Pray, also see the income smoothing as reflecting the administration's desire to minimize unexpected income distortions. "It is supposed to reduce the variance and fluctuations in the income figures for different accounting periods," said Shirazi, 1990. The accounting practices through which this effect can achieve are as large as the basis of recognition (timing of recognition) revenue, the basis of recognition (timing of recognition) expenditure, methods of tabulation of ordinary and extraordinary items in the income statement, and the desire of the administration to avoid showing the variation in the results of the establishment from time to time, in other words, it is a kind of blurring of facts or temporarily abandons them from the owners which leads to misdirection of resources among alternative investment areas.

Earnings management: Since the rise of net profit is a significant indicator for the investor, gives the impression of a valid performance of the company and the safety of its financial position and reduces the fear of the level of risk attached to it; the administration was interested in loading this element of accounting specifically- net profit- accounting methods were adopted to control these profits, and distribute them as it deems appropriate in light of the available accounting options and choices, which is called the earnings management. It is defined by Sthipper, 1989 as "deliberate intervention by management in the process of measurement and external financial reporting to obtain special gains to the company or its management." Earnings management is one of the most important forms of creative accounting discussed in accounting literature.
Creative Accounting: "Some or all of the steps had used to practice the game of financial figures, including the arbitrary selection of accounting principles, fraud in the financial report and any other procedures taken to earnings management or income smoothing (Levitt. 1998).

\section{e) The concept of earnings management}

The net profit index is beneficial for both investors and management; therefore, the administration seeks to streamline profits to improve the financial position of companies in the stock market or to demonstrate their good conduct through accounting procedures called earnings management. Both Healy and Wahlen, 1999, defined earnings management as; a change in corporate financial reporting by insiders, to either, mislead some stakeholders or influence the contractual results, which depend on the figures in the financial reports. Leuz et al; 2003 acknowledged this definition. It is defined by Sthipper, 1989 as "deliberate intervention by management in the process of measurement and external financial reporting with obtaining special gains to the company or its management." Linda Halabi, 2009 also defined earnings management as manipulation of income to achieve a pre-defined goal by administration, or predicted by a financial analyst, or to be consistent with specific courses of action; the study sees that the earnings management is a trial from insiders in companies to protect their interests and their positions by manipulating financial information which had provided to third parties. Several researchers, such as Van Pray, Trueman and Dahran, distinguish between the concept of income smoothing and the concept of earnings management (Habib, 2003). The first expresses the management's desire to reduce the unexpected deviations in income to as much as possible, While the second came across as the request of the administration to reach specific goals, including increased managerial incentives, or reduce tax payments or reduce borrowing costs. Profit management is one of the most important forms of creative accounting in accounting literature. It has classified into two types: the real earnings management, which affect cash flows, and earnings management through the administration of accruals through changes in accounting policies and estimates. The second type is the most common, which falls under the concept of innovative accounting. But the first type - real management-may involve fraud and violation of principles. Accounting literature relied primarily on the consideration of the discretionary accruals component to detect the earnings management in companies because the discretionary accruals constitute the difference between profits and cash flows. Several researchers (Berton and Stolowy, 2000 and Skinner and Dechow, 2000) believe that the earnings 
management of this kind - accrual management - does not include changing the facts, but another way to deal with the apparent differences in short-term earnings, by bringing profits to the year in need and paying expenses. Earnings management also has a common accounting approach to dealing with losses called Big Bath Accounting, Where the Big Bath hypotheses suggest the method of reducing the estimates of earnings and profits of the company in a certain period against the overstatement of losses. This approach aims to eliminate accumulated losses in a year of losses, by doubling losses (overestimated) to ensure better profits in the coming year or years.

Several researchers (Berton and Stolowy, 2000) (Jiang, 2006) (Shuto, 2007) also believe that managerial compensation plans have the best impact in adopting this approach, where the new CEO blame for the company's loss on the former manager, while at the same time ensuring an increase in its share of subsequent managerial compensation, as it has linked to the earnings rate which will undoubtedly be better in the coming years. The earning management and the income smoothing had mostly done using several tools, including taxes on investments, classification of extraordinary items in the income statement, dividends, gains and losses on securities, pension funds, research and development expenses, advertising expenses, inventory, depreciation and currency conversion.

The following definitions are:

\section{f) Measuring earnings management}

The issue of measurement of earnings management has challenged, and researchers have developed multiple methods of measurement, including the model developed by Leaz et al. 2003, which had based on the previous work of (Dechow, Sloan, and Sweeny, 1995; Healy and Whalen, 1999, and Skinner and Dechow, 2000). Therefore, earnings management should be classified as follows: manipulate earnings (EM1, EM2) and aggressive earnings (EM3). The insiders can mitigate and reduce the fluctuations in earnings by changing the receivables of revenues and expenses.

The operational definition of receivables is as follows: Accruals

$$
=(\text { DCA }- \text { Dcash })-(\text { DCL }- \text { DSTD }- \text { DTP })-\text { Dep Equ. }
$$

Where:

DCA: Change in Total Current Assets

Dash: Change in cash and equivalents

DCL: Change in total current liabilities

DSTD: Change in short term borrowings included in current liabilities

DTP: Change in income tax payable

Dep: Depreciation and amortization expenses

We can then calculate cash flows from the following operations:
Cash flow from operations=Operating earningsAccruals Equ. (2)

Earnings management EM1 measures the degree to which insiders can use their powers to alert receivables and thus reduce operating profit volatility:

EM1 = SD (Operating earnings)/SD (Cash flow from operations) Equ. (3)

\section{Where:}

SD Standard deviation: Cash flows from operations have been identified in equation (2).

The low value of this measure reveals that insiders use their powers to facilitate declared profits, while the high value of this measure shows that the company is less likely to earnings management. And the implicit assumption that there will be fluctuations in operating earnings on an accrual basis against cash flows from operations. If the fluctuations in operating earnings are small compared to change in the cash movements of operations, this indicates that the management uses the estimated receivables to manipulate operating earnings.

EM2: Based on the new correlation between change in receivables and changes in cash flows from operations. This measure has based on the idea that insiders attempt to conceal the shortage of cash flows by manipulating receivables.

EM2 = Spearman (DAc cruals, Cash flow from operations) Equ. (4).

Spearman is the Spearman correlation coefficient used to measure the correlation between two variables. The correlation coefficient is good +1 if there is a positive correlation between the two variables, and would be -1 if the correlation between the two variables is negative. If the coefficient of correlation is zero, this means that there is no correlation between the two variables. Insiders may use their estimates to report on accounting receivables that compensate for the economic shocks of cash flows from operations, which in turn will affect declared profits. The existence of a negative correlation means the use of the estimated receivables to offset the unwanted cash flows and hence clearly demonstrates the earnings management. So the greater the EM2 value, the less likely there is to earnings management.EM3 shows aggressive earnings. They are used by insiders in their reports to distort and defect the actual economic performance. The assumption is that the receivables of companies that want to manipulate the earnings to have reported will be wider than cash flows from operations.

Therefore, EM3 is to compare the absolute value of receivables and the entire value of cash flows from operations using the following equation: 
$\mathrm{EM} 3=1$ Accruals A Cash flow from equations Equ. (5)

The larger the EM3, the greater the significance of the use of receivables on a wide scale to distort reports on accounting earnings.

g) Methods of earnings management

Earnings management has used through the following methods:
First: Use of earnings management methods through the income statement. Net income has manipulated, as shown in the following table (Schilit, 2002), (Howard, 2002):

Methods of earnings management to manipulate the income statement

\begin{tabular}{|l|l|}
\hline \multicolumn{1}{|c|}{ Item } & \multicolumn{1}{|c|}{ Methods of earnings management } \\
\hline The sales & $\begin{array}{l}\text { 1. Make nonreal sales transactions to had } \\
\text { canceled during the following year. }\end{array}$ \\
\hline $\begin{array}{l}\text { 2. Make real sales transactions on easy terms. } \\
\text { 3. Registration of the Secretariat's goods had } \\
\text { sent to the agencies as sales. }\end{array}$ \\
\hline Cost of goods sold & $\begin{array}{l}\text { 1. The entity liquidates the commodity } \\
\text { inventory, which has been valued by the } \\
\text { LIFO method. }\end{array}$ \\
\hline 2. Unjustified change in inventory valuation \\
method.
\end{tabular}

Second: Use of earnings management methods through the statement of financial position, as shown in the following table (Al-Halabi, 2009):

Methods of earnings management in the statement of financial position

\begin{tabular}{|l|r|}
\hline \multicolumn{1}{|c|}{ Item } & \multicolumn{1}{|c|}{ Methods of earnings management } \\
\hline Cash & $\begin{array}{l}\text { 1. Non-disclosure of registered cash items. } \\
\text { 2. Manipulation of exchange rates when } \\
\text { translating transactions in a foreign } \\
\text { currency. }\end{array}$ \\
\hline Current investments & $\begin{array}{l}\text { 1. Manipulate market prices when evaluating a } \\
\text { financial portfolios. }\end{array}$ \\
2. They are manipulating the classification of \\
investments, such as the classification of \\
traded ones to long-term when falling.
\end{tabular}




\begin{tabular}{|c|c|}
\hline Inventory & $\begin{array}{l}\text { 1. Inventory lists include stagnant or obsolete } \\
\text { goods. } \\
\text { 2. They are intentionally manipulating for } \\
\text { prices. } \\
\text { 3. Unjustified change in stock pricing method } \\
\text { from FIFO to WA. }\end{array}$ \\
\hline $\begin{array}{l}\text { Long-term } \\
\text { investments }\end{array}$ & $\begin{array}{l}\text { 1. Change the accounting method for long- } \\
\text { term investments from the cost method to } \\
\text { equity method. } \\
\text { 2. Avoid showing the parent company's share of } \\
\text { the losses of the subsidiary or associate. } \\
\text { 3. Not to exclude the effect of mutual } \\
\text { transactions between the holding company } \\
\text { and the subsidiary. }\end{array}$ \\
\hline $\begin{array}{l}\text { Property, Plant, and } \\
\text { equipment }\end{array}$ & $\begin{array}{l}\text { 1. Non-compliance with the historical cost } \\
\text { principle and the adoption of revaluation at } \\
\text { market value and showing a surplus in } \\
\text { income statement rather than equity. } \\
\text { 2. Reduce consumption rates in the market. } \\
\text { 3. Unjustifiable change in consumption } \\
\text { methods. } \\
\text { 4. Reclassification of certain assets between } \\
\text { fixed and current assets and long-term } \\
\text { investments. } \\
\text { 5ot to disclose the encumbered assets as } \\
\text { collateral for the loan. }\end{array}$ \\
\hline Intangible assets & $\begin{array}{l}\text { 1. Overvaluation of the intangible assets } \\
\text { resulting from the merger. } \\
\text { 2. Register of intangible assets not purchased. } \\
\text { 3. Reduce the amortization rate of intangible } \\
\text { assets over the recognized rates. }\end{array}$ \\
\hline Current liabilities & $\begin{array}{l}\text { 1. Non-accruals of long-term loans are not } \\
\text { included in current liabilities to improve the } \\
\text { liquidity ratio. } \\
\text { 2. Repayment of a short-term loan through } \\
\text { long-term borrowing to improve liquidity } \\
\text { ratios. } \\
\text { 3. Suspend receipt of advance payments to } \\
\text { improve leverage rates. }\end{array}$ \\
\hline Long-term liabilities & $\begin{array}{l}\text { 1. Obtain long-term loans before the end of } \\
\text { the fiscal year to repay a short-term loan to } \\
\text { improve liquidity ratios. } \\
\text { 2. Extinguish callable deposits before maturity } \\
\text { and add gains to net profit rather than } \\
\text { extraordinary items. }\end{array}$ \\
\hline Shareholders' equity & $\begin{array}{l}\text { 1. Adding previous years 'gains to current } \\
\text { years' profits rather than being included in } \\
\text { retained earnings. } \\
\text { 2. Include exchange gains or losses on equity } \\
\text { instead of the income statement. } \\
\text { 3. Incorporation of gains or losses on } \\
\text { translation of financial statements in the } \\
\text { income statement rather than equity. }\end{array}$ \\
\hline $\begin{array}{l}\text { Contingent assets } \\
\text { and liabilities }\end{array}$ & $\begin{array}{l}\text { 1. Register probable assets before they have } \\
\text { acquired as revenue expected to be } \\
\text { collected from a lawsuit before judgment } \\
\text { has rendered. } \\
\text { 2. Obligation to disclose contingent or } \\
\text { contingent obligations. }\end{array}$ \\
\hline
\end{tabular}

Third: Earnings management techniques in the Cash Flow Statement: Earnings management occurs through the cash flow statement as follows:

1. The accountant classifies operating expenses as investment expenses or financing expenses. Cash financing expenses can also have classified as operating cash, and these do not change the final values.

2. Payment of capital development costs, and recording them as external cash inflows and taking it away from cash outflows.

3. The purpose of the manipulation of operational cash flows is to escape partly from paying taxes. One 
example is the reduction of the gain on the sale of investments from net income during the calculation of operating cash flows.

Fourth: Earnings management techniques in the statement of changes in equity:

Earnings management procedures are being carried by making fictitious changes in the increase or reduction of paid capital, as well as the acquired and calculated principles, which have exercised to recalculate the size of previous mistakes or losses of previous options and balances of foreign currencies (Jarrar, 2006).

h) The impact of the shift to IFRS on the earnings management

All professional organizations advocate the need to apply IFRS to increase disclosure and transparency in financial statements. These standards began to replace some of the International Accounting Standards (IAS) in 2005 gradually. The International Financial Reporting Standards Committee clarified that it aims to introduce several changes, including the elimination of the majority of alternatives (standard and alternative treatment). In the current international accounting standards and to have only one accounting treatment, with the aim of standardization and ease of comparison. And work to eliminate the contradictions and conflicts between some of the criteria in addition to the vagueness of some. And the introduction of the interpretations attached to the standards within the accounting standards themselves rather than being separated in an annex to each gauge. And add enclosures to each accounting standard that explains how to apply.

Also, companies in the G-20 have begun to adopt IFRS standards but in a limited way and prepare their financial reports accordingly. According to the International Accounting Standards Board (IASB), more than 100 countries have adopted IFRS standards (IASB, 2009). The United States was considering adopting these standards in 2011. Due to the many problems in the transition from GAAP to IFRS standards, the US Securities and Exchange Commission changed the beginning of the adoption of IFRS standards to 2015. It defines a set of considerations must be taken into account before the implementation of IFRS standards (Steven M. Mintz, 2010): adequate development of accounting systems to allow the performance of IFRS Standards, the authors of those standards should be independent enough, and give courses for investors to understand the effects of these standards, and the examination of the organizational environment in the United States, which will be affected by changes in accounting standards, the availability of the legal and legislative environment, and the availability of human resources.

With the adoption of IFRS standards on an imminent global scale, there is an opportunity to check whether IFRS standards improve the quality of accounting information and provide benefits to investors; there are a range of advantages that companies can obtain if they apply IFRS when preparing their financial statements, including access to global markets, ease of access to finance, low longterm cost of capital, low price of preparing financial statements, transfer of knowledge about IFRS to practitioners, and improved learning opportunities for practitioners from accountants.

\section{Research Methodology}

The research had based on the inductive and deductive approaches, in which a review was done to what has been stated in accounting thoughts in general and in the field of international standards for the preparation of financial reports in particular, to reaching a theoretical framework for research. Based on this framework, a field study was done conducted on a sample of Saudi shareholding companies in different sectors whose shares are traded on the Saudi Stock Exchange, to learn about the impact of changing these companies to international standards on limiting its earnings management, which reflected in the quality of the accounting information provided by the financial reports in these companies. The study society consists of the shareholding companies whose shares had traded on the Saudi Stock Exchange in the various sectors, and they are 145 companies (according to the Tadawul website). All of them have sent questionnaires. The following table shows the sender and recipient of these questionnaires:

Table 1: Establishments representing the society of the study

\begin{tabular}{|c|l|c|c|}
\hline No. & \multicolumn{1}{|c|}{ The Sector } & $\begin{array}{c}\text { No. of sent } \\
\text { questionnaires }\end{array}$ & $\begin{array}{c}\text { No. of received } \\
\text { questionnaires }\end{array}$ \\
\hline 1 & $\begin{array}{l}\text { Banks and Financial } \\
\text { Services }\end{array}$ & 15 & 11 \\
\hline 2 & Petrochemical Industries & 12 & 8 \\
\hline 3 & Cement & 9 & 7 \\
\hline 4 & Retail & 16 & 10 \\
\hline 5 & Energy and utilities & 2 & 1 \\
\hline
\end{tabular}




\begin{tabular}{|c|c|c|c|}
\hline 6 & $\begin{array}{l}\text { Agriculture and food } \\
\text { industries }\end{array}$ & 14 & 10 \\
\hline 7 & $\begin{array}{l}\text { Communications and } \\
\text { Information Technology }\end{array}$ & 5 & 3 \\
\hline 8 & Insurance & 25 & 18 \\
\hline 9 & $\begin{array}{l}\text { Multi-investment } \\
\text { companies }\end{array}$ & 7 & 4 \\
\hline 10 & Industrial Investment & 12 & 8 \\
\hline 11 & Construction & 15 & 10 \\
\hline 12 & Real estate development & 8 & 5 \\
\hline 13 & Transportation & 5 & 2 \\
\hline 14 & Hotels and Tourism & 2 & 2 \\
\hline 15 & Media and Publishing & 2 & - \\
\hline Total & & 149 & 100 \\
\hline
\end{tabular}

a) Distribution of sample by sector

The following table shows the sample distribution by economic sector followed by the sample companies. Showing the number of companies selected from each section as well as the percentage of the number chosen as follows:

Table 2: Sample distribution according to economic sectors

\begin{tabular}{|c|l|c|c|}
\hline No. & \multicolumn{1}{|c|}{ The Sector } & $\begin{array}{c}\text { No. of } \\
\text { companies }\end{array}$ & 11 \\
\hline 1 & $\begin{array}{l}\text { Banks and Financial } \\
\text { Services }\end{array}$ & 11 & 8 \\
\hline 2 & Petrochemical Industries & 8 & 7 \\
\hline 3 & Cement & 7 & 10 \\
\hline 4 & Retail & 10 & 1 \\
\hline 5 & Energy and utilities & 10 & 10 \\
\hline 6 & $\begin{array}{l}\text { Agriculture and food } \\
\text { industries }\end{array}$ & 3 & 18 \\
\hline 7 & $\begin{array}{l}\text { Communications and } \\
\text { Information Technology }\end{array}$ & 18 & 4 \\
\hline 8 & Insurance & 4 & 8 \\
\hline 9 & $\begin{array}{l}\text { Multi-investment } \\
\text { companies }\end{array}$ & 10 & 10 \\
\hline 10 & Industrial Investment & 5 & 5 \\
\hline 11 & Construction & 3 & 3 \\
\hline 12 & Real estate development & 100 & 2 \\
\hline 13 & Transportation & & 100 \\
\hline 14 & Hotels and Tourism & 10 & \\
\hline Total & & & 10 \\
\hline & & & \\
\hline
\end{tabular}

b) Characteristics of the study sample

Table 3

\begin{tabular}{|l|l|c|c|}
\hline Variable & \multicolumn{1}{|c|}{ Category } & Number & $\%$ \\
\hline Function & $\begin{array}{l}\text { Financial Manager } \\
\text { Head of Accounts Section }\end{array}$ & 21 & 10 \\
\hline
\end{tabular}




\begin{tabular}{|l|l|l|l|} 
& First Accountant & 21 & 21 \\
& Second Accountant & 17 & 17 \\
& Trainee Accountant & 17 & 17 \\
Qualification & Others & 14 & 14 \\
& Average Diploma & 24 & 24 \\
& Bachelor and high diploma & 63 & 63 \\
Experience & Postgraduate & 13 & 13 \\
& Less than six years & 49 & 49 \\
& From 6 to 12 years & 29 & 29 \\
\hline & More than 12 years & 22 & 22 \\
\hline
\end{tabular}

It is clear from Table (3) that the respondents to the questionnaire are financial managers and their proportion of $10 \%$, and $21 \%$ top of accounts sections, and $21 \%$ first accountants, as well as a second accountant, trainee accountant their percentages, were $17 \%$ and $7.8 \%$ respectively, other accountant jobs, representing $14 \%$ of the total sample, but all jobs are in accounting, which can be reassuring to their answers. As shown in table (3), $63 \%$ of the group has a bachelor's degree and a high diploma in accounting, which can also be reassuring to the answers received from them on this questionnaire, and that their response represent to some extent the reality of accounting profession in the Kingdom of Saudi Arabia, including the Masters and Ph.D. degrees 13\% each.
Finally, it is clear from the previous table that $49 \%$ have experience up to 6 years, and that 29\% have experience ranging from 6 to 12 years, and $22 \%$ of the accountants in the sample have more than 12 years experience. These ratios make it possible to rely on answers.

c) Stability of the study tool

The consistency of the study questionnaire was verified by extracting the internal consistency coefficient, depending on the equation Cronbach Alpha for each variable in all dimensions of the study variables. The stability coefficients of all the variables were high, which are great stability rates and acceptable in human research and studies. Table (4) shows the results of the test.

Table 4: The stability coefficient values for each variable of the example

\begin{tabular}{|l|l|c|c|}
\hline Study variables & \multicolumn{1}{|c|}{ Dimensions } & $\begin{array}{c}\text { Interval } \\
\text { s }\end{array}$ & $\begin{array}{l}\text { Cronbac } \\
\text { h factor } \\
\text { Alpha }\end{array}$ \\
\hline $\begin{array}{l}\text { Earnings } \\
\text { Management }\end{array}$ & $\begin{array}{l}\text { Earnings Management by } \\
\text { manipulating expenses in the } \\
\text { income statement } \\
\text { Earnings Management by } \\
\text { manipulating revenue in the } \\
\text { income statement } \\
\text { Earnings management by } \\
\text { manipulating the accounts of the } \\
\text { financial position } \\
\text { Earnings management by } \\
\text { manipulating the cash flow } \\
\text { statement accounts } \\
\text { Earnings management by } \\
\text { manipulating changes in the list of } \\
\text { equity } \\
\text { The quality of expected } \\
\text { accounting information after the } \\
\text { expected conversion of IFRS } \\
\text { standards compared to local Saudi } \\
\text { standards }\end{array}$ & $10-21$ & 0.78 \\
\hline $\begin{array}{l}\text { Quality of } \\
\text { expected } \\
\text { accounting } \\
\text { information }\end{array}$ & \begin{tabular}{l} 
Eand \\
\hline
\end{tabular} & $52-60$ & 0.81 \\
\hline
\end{tabular}

d) Statistical Processing

SPSS statistical package had used to conduct descriptive analysis to answer the study's questions and test hypotheses as shown:
1. The mean and standard deviations and t-test for one sample to test the initial assumption.

2. Multiple regression tests for the second hypothesis. 
3. Analysis of the mono-variance to test the third and fourth hypotheses, as well as the Schiffe test for post comparisons.

\section{The Results}

First: Test the first basic assumption that reads: There is no expected change in earnings management in light of the transition to IFRS., and its sub-assumptions arising from it:
To test the first basic assumption, and its subassumptions arising from it, the accounting averages and standard deviations of the expected change in earnings management were extracted in light of the transition to IFRS, in addition to the use of t-test for one sample compared to the mean (3), and table (5) shows that.

Table 5: Averages and standard deviations and the t-test results of the expected change in earnings management in light of the transition to IFRS

\begin{tabular}{|c|c|c|c|c|c|c|}
\hline $\begin{array}{l}\text { Hypot } \\
\text { hesis }\end{array}$ & $\begin{array}{c}\text { Earnings management } \\
\text { dimensions }\end{array}$ & $\begin{array}{c}\text { Avera } \\
\text { ge }\end{array}$ & $\begin{array}{l}\text { stand } \\
\text { ard } \\
\text { devia } \\
\text { tion }\end{array}$ & $\begin{array}{l}\text { Avera } \\
\text { ge } \\
\text { differ } \\
\text { ence }\end{array}$ & $\begin{array}{l}\text { Calculat } \\
\text { ed t- } \\
\text { teas }\end{array}$ & $\begin{array}{l}\text { Probabilit } \\
\text { y Value }\end{array}$ \\
\hline $\mathrm{H} 1.1$ & $\begin{array}{l}\text { Earnings Management by } \\
\text { manipulating expenses in } \\
\text { the income statement }\end{array}$ & 3.18 & 0.70 & 0.18 & 2.606 & $0.011 x$ \\
\hline $\mathrm{H} 1.2$ & $\begin{array}{l}\text { Earnings management by } \\
\text { manipulating revenue in } \\
\text { the income statement }\end{array}$ & 3.28 & 0.65 & 0.28 & 4.268 & $0.000 x$ \\
\hline $\mathrm{H} 1.3$ & $\begin{array}{l}\text { Earnings management by } \\
\text { manipulating the accounts } \\
\text { of the financial position }\end{array}$ & 3.30 & 0.60 & 0.30 & 4.988 & $0.000 x$ \\
\hline $\mathrm{H} 1.4$ & $\begin{array}{l}\text { Earnings management by } \\
\text { manipulating the cash } \\
\text { flow statement }\end{array}$ & 3.60 & 0.66 & 0.60 & 9.117 & $0.000 x$ \\
\hline $\mathrm{H} 1.5$ & $\begin{array}{l}\text { Earnings management by } \\
\text { manipulating changes in } \\
\text { statement equity }\end{array}$ & 3.35 & 0.86 & 0.35 & 4.022 & $0.000 x$ \\
\hline $\mathrm{H} 1$ & Earnings Management & 3.31 & 0.54 & 0.31 & 5.688 & $0.000 x$ \\
\hline
\end{tabular}

$x$ means statistically significant at the level of $(a=0.05)$

The results in Table (3) show that the calculated t value of the change in the total earnings management was (5.688) with a chance of (0.000), which is less than the level of significance $(a=0.05)$, Thus rejecting the null assumption (primary principle) and accepting the alternative hypothesis that "there is an expected change in earnings management in light of the transition to IFRS," and the mean difference was (0.31) compared to the hypothetical mean (3).

The results also showed that the value of (t) calculated for change in expenses in the income statement was (2.606) with a probability of $(0.011)$, which is less than the significance level $(a=0.05)$, thus rejecting the null hypothesis $(\mathrm{H} 1.1)$ and accept the alternative assumption, which states "there is an expected change in earnings management in light of the transition to IFRS by manipulating expenses in the income statement," and the mean difference was (0.18) compared to the hypothetical mean (3).

The results also showed that the value of (t) calculated for change in revenue in the income statement was (4.268) with a probability of (0.000), which is less than the significance level $(a=0.05)$, thus rejecting the null hypothesis $(\mathrm{H} 1.2)$ and accept the alternative assumption, which states "there is an expected change in earnings management in light of the transition to IFRS by manipulating revenue in the 
income statement," and the mean difference was (0.28) compared to the hypothetical mean (3).

The results also showed that the value of (t) calculated for change in the accounts of the financial position was (4.988) with a probability of (0.000), which is less than the significance level $(a=0.05)$, thus rejecting the null hypothesis $(\mathrm{H} 1.3)$ and accept the alternative assumption, which states "there is an expected change in earnings management in light of the transition to IFRS by manipulating the accounts of the financial position," and the mean difference was (0.30) compared to the hypothetical mean (3).

The results also showed that the value of (t) calculated for change in the cash flow statement was (9.117) with a probability of $(0.000)$, which is less than the significance level $(a=0.05)$, thus rejecting the null hypothesis ( $\mathrm{H} 1.4)$ and accept the alternative assumption, which states "there is an expected change in earnings management in light of the transition to IFRS by manipulating the cash flow statement," and the mean difference was (0.60) compared to the hypothetical mean (3).
Finally, the results showed that the value of (t) calculated for change in the statement of equity was (4.022) with a probability of $(0.000)$, which is less than the significance level $(a=0.05)$, thus rejecting the null hypothesis (H5.2) and accept the alternative assumption, which states "there is an expected change in earnings management in light of the transition to IFRS by manipulating changes in the list of equity," and the mean difference was (0.35) compared to the hypothetical mean (3).

Second: Test the second basic assumption that reads: There is no statistically significant impact at the level of indication $(a=0.05)$ of the shift in IFRS to improve the quality of accounting information and to test this hypothesis, a multiple regression test had used to determine the impact of the shift to IFRS (expenses in the income statement, revenue in the income statement, the accounts of the financial position, the cash flow statement, list of equity) in improving the quality of accounting information. Table (6) shows the results of the test.

Table 6: The results of the multiple regression for the impact of alteration to IFRS on improving the quality of accounting information

\begin{tabular}{|c|c|c|c|c|c|c|}
\hline $\begin{array}{c}\text { Earnings management } \\
\text { dimensions }\end{array}$ & Beta & $\begin{array}{c}\text { Calcula } \\
\text { ted } t\end{array}$ & $\begin{array}{l}\text { Signifi } \\
\text { cance } \\
\text { level }\end{array}$ & $\begin{array}{c}\mathbf{r} \\
\text { squar } \\
e\end{array}$ & $\begin{array}{l}\text { Calcul } \\
\text { ated } \mathbf{f}\end{array}$ & $\begin{array}{c}\text { Proba } \\
\text { bility } \\
\text { Value }\end{array}$ \\
\hline $\begin{array}{l}\text { Earnings Management } \\
\text { by manipulating } \\
\text { expenses in the income } \\
\text { statement } \\
\text { Earnings management } \\
\text { by manipulating } \\
\text { revenue in the income } \\
\text { statement }\end{array}$ & 0.004 & 0.030 & $\begin{array}{l}0.590 \\
0.967\end{array}$ & & & \\
\hline $\begin{array}{l}\text { Earnings management } \\
\text { by manipulating the } \\
\text { accounts of the } \\
\text { financial position } \\
\text { Earnings management } \\
\text { by manipulating the } \\
\text { cash flow statement } \\
\text { Earnings management } \\
\text { by manipulating } \\
\text { changes in list equity }\end{array}$ & $\begin{array}{l}0.425 \\
0.411\end{array}$ & 3.384 & $\underset{\times}{0.001}$ & 0.234 & 5.751 & $\underset{\times}{0.000}$ \\
\hline
\end{tabular}

$x$ means statistically significant at the level of $(a=0.05)$

Note from Table (6) that the value of the calculated $(\mathrm{f})$ is (5.751) with a probability value $(0.000)$, which is less than the significance level $(a=0.05)$, indicating a statistically significant impact on the transition to IFRS in improving the quality of accounting information. The table also shows that the dimensions of earnings management (expenses in the income statement, revenue in the income statement, the accounts of the financial position, the cash flow statement, list of equity) explain $23.4 \%$ of the change in the quality of accounting information.

The table also indicates that the dimensions of earnings management (the accounts of the financial position, the cash flow statement, list of equity) have an impact on the quality of the accounting information, where the values of $(t)$ were $(3.398,3.384,2.151)$ 
respectively, with probability values (0.001, $0,001,0.034)$, which is less than the significance level $(a=0.05)$. The follow-up of beta factors for these dimensions shows that the accounts of the financial position dimension is the most powerful of the earnings dimensions in affecting the quality of the accounting information, with a beta value of (0.425). It also becomes apparent that the two earnings management dimensions (expenses in the income statement, revenue in the income statement) has no effect on the quality of accounting information, where the values of (t) for them were $(0.541,0.030)$, respectively, with probability values $(0.590,0.976)$, respectively, which is greater than the significance level $(a=0.05)$.

Based on these results, the alternative hypothesis is accepted "there is a statistically significant impact at the significance level of $(a=0.05)$ of the transition to IFRS (the accounts of the financial position, the cash flow statement, list of equity) in improving the quality of accounting information." The null hypothesis was also accepted: "There is no statistically significant impact at the significance level of $(a=0.05)$ of the transition to IFRS (expenses in the income statement, revenue in the income statement) in improving the quality of accounting information."

Third: Test the third basic assumption that reads: There is no statistically significant impact at the level of indication $(\mathrm{a}=0.05)$ in the expected change in earnings management in light of the transition to IFRSs attributable to the accounting qualification of accountants and to test this hypothesis, single variance analysis had used to determine the differences in the expected change in earnings management in light of the transition to IFRS due to the qualification of the accountants. Table (7) shows the results of the analysis.

Table 7: The results of the single variance of the differences in the expected change in earnings management in light of the transition to IFRS due to the qualification of the accountants

\begin{tabular}{|c|c|c|c|c|c|}
\hline $\begin{array}{c}\text { Earnings } \\
\text { management } \\
\text { dimensions }\end{array}$ & Qualification & $\begin{array}{c}\text { Avera } \\
\text { se }\end{array}$ & $\begin{array}{c}\text { Standa } \\
\text { rd } \\
\text { deviati } \\
\text { on }\end{array}$ & $\begin{array}{l}\text { Calcul } \\
\text { ated } f\end{array}$ & $\begin{array}{l}\text { Proba } \\
\text { bility } \\
\text { Value }\end{array}$ \\
\hline $\begin{array}{l}\text { Earnings } \\
\text { Management by } \\
\text { manipulating } \\
\text { expenses in the } \\
\text { income statement }\end{array}$ & $\begin{array}{l}\text { Average Diploma } \\
\text { Bachelor and high } \\
\text { diploma } \\
\text { Postgraduate }\end{array}$ & $\begin{array}{l}3.20 \\
3.11 \\
3.50\end{array}$ & $\begin{array}{l}0.55 \\
0.79 \\
0.36\end{array}$ & 1.754 & 0.178 \\
\hline $\begin{array}{l}\text { Earnings } \\
\text { management by } \\
\text { manipulating } \\
\text { revenue in the } \\
\text { income statement }\end{array}$ & $\begin{array}{l}\text { Average Diploma } \\
\text { Bachelor and high } \\
\text { diploma } \\
\text { Postgraduate }\end{array}$ & $\begin{array}{l}3.33 \\
3.29 \\
3.08\end{array}$ & $\begin{array}{l}0.49 \\
0.75 \\
0.28\end{array}$ & 0.691 & 0.504 \\
\hline $\begin{array}{l}\text { Earnings } \\
\text { management by } \\
\text { manipulating the } \\
\text { accounts of the } \\
\text { financial position }\end{array}$ & $\begin{array}{l}\text { Average Diploma } \\
\text { Bachelor and high } \\
\text { diploma } \\
\text { Postgraduate }\end{array}$ & $\begin{array}{l}3.12 \\
3.35 \\
3.38\end{array}$ & $\begin{array}{l}0.51 \\
0.64 \\
0.51\end{array}$ & 1.453 & 0.239 \\
\hline $\begin{array}{l}\text { Earnings } \\
\text { management by } \\
\text { manipulating the } \\
\text { cash flow } \\
\text { statement }\end{array}$ & $\begin{array}{l}\text { Average Diploma } \\
\text { Bachelor and high } \\
\text { diploma } \\
\text { Postgraduate } \\
\text { Average Diploma }\end{array}$ & $\begin{array}{l}3.69 \\
3.62 \\
3.37 \\
3.28\end{array}$ & $\begin{array}{l}0.62 \\
0.70 \\
0.52 \\
0.72\end{array}$ & 1.044 & 0.356 \\
\hline
\end{tabular}

Table (7) shows no statistically significant differences at the significance level $(a=0.05)$ in the expected change in earnings management in light of the transition to IFRS due to the qualification of the accountants, since the value of the calculated ( $f$ ) for the expenses in the income statement was (1.754), for the revenue in the income statement (0.691), for the accounts of the financial position (1.453), for the cash flow statement (1.044), for list of equity (0.100), and the earnings management as a whole (0.175), with probability values $(0.178,0.504,0.329,0.356,0.905$, and 0.839 ) respectively, which is more than the significance level of $(a=0.05)$. Based on these results, the null hypothesis had accepted: "There is no statistically significant impact at the significance level of (a $=0.05$ ), in the expected change in earnings management in light of the transition to IFRS due to the qualification of the accountants".

Fourth: Test the fourth basic assumption that reads: There is no statistically significant impact at the significance level of $(a=0.05)$ in the expected change in earnings management in light of the transition to IFRSs attributable to the experience of accountants and 
to test this hypothesis, single variance analysis had used to determine the differences in the expected change in earnings management in light of the transition to IFRS due to the experience of the accountants. Table (8) shows the results of the analysis.

Table 8: The results of the single variance of the differences in the expected change in earnings management in light of the transition to IFRS due to the experience of the accountants

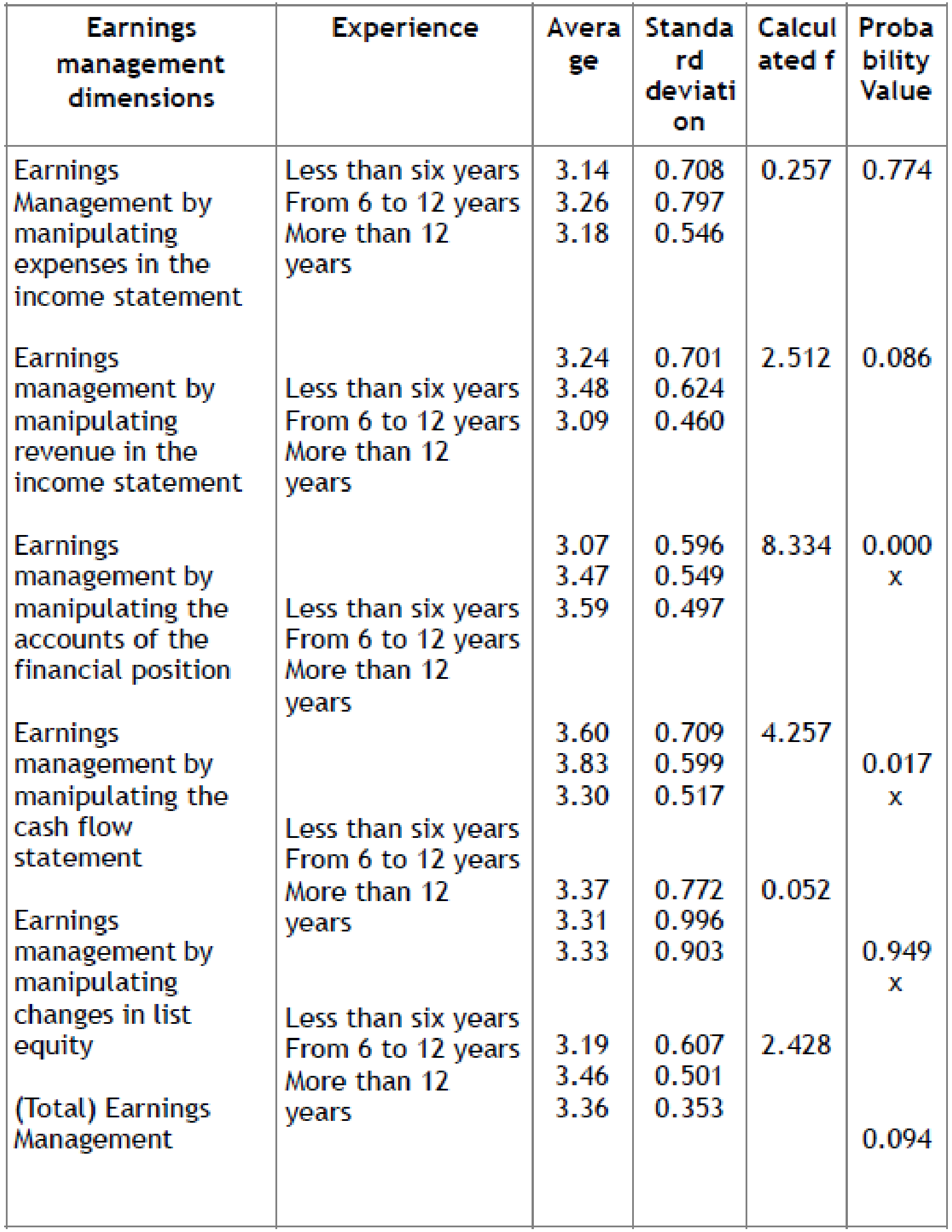


Table (8) shows no statistically significant differences at the significance level $(a=0.05)$ in the expected change in earnings management in light of the transition to IFRS (expenses in the income statement, revenue in the income statement, list of equity, earnings management as a whole) due to the experience of the accountants, since the value of the calculated (f) for the expenses in the income statement was (2.512), for the revenue in the income statement (2.512), for list of equity (0.052), and the earnings management as a whole (2.428), with probability values $(0.774,0.086,0.949,0.356$, and 0.094)respectively, which is more than the significance level of $(a=0.05)$.
The results also indicated that there were statistically significant differences at the significance level of $(a=0.05)$ in the expected change in earnings management in light of the transition to IFRS (the accounts of the financial position, the cash flow statement) due to the experience of the accountants since the value of the calculated ( $f$ ) for the accounts of the financial position was (8.334), and for the cash flow statement (4.257), with probability values $(0.000$, and $0.017)$ respectively, which is less than the significance level of $(a=0.05)$. To determine the direction of these differences, use the Schiffe test for post-comparisons. Table (9) shows the test results.

Table 9: Results of Schiffe test for the expected change in earnings management in light of the transition to IFRS (the accounts of the financial position, the cash flow statement) due to the experience of the accountants

\begin{tabular}{|c|c|c|c|c|c|}
\hline $\begin{array}{l}\text { Earnings } \\
\text { management } \\
\text { dimensions }\end{array}$ & Experience & $\begin{array}{c}\text { Avera } \\
\text { ge }\end{array}$ & $\begin{array}{l}\text { Less } \\
\text { than } 6 \\
\text { years }\end{array}$ & $\begin{array}{l}\text { From } \\
6 \text { to } \\
12 \\
\text { years }\end{array}$ & $\begin{array}{l}\text { More } \\
\text { than } \\
12 \\
\text { years }\end{array}$ \\
\hline $\begin{array}{l}\text { Earnings } \\
\text { management by } \\
\text { manipulating the } \\
\text { accounts of the } \\
\text { financial position }\end{array}$ & $\begin{array}{l}\text { Less than six years } \\
\text { From } 6 \text { to } 12 \text { years } \\
\text { More than } 12 \\
\text { years }\end{array}$ & $\begin{array}{l}3.07 \\
3.47 \\
3.59\end{array}$ & - & $\begin{array}{c}-.40 \\
-\end{array}$ & $\begin{array}{l}0.52 x \\
0.12 \\
-\end{array}$ \\
\hline $\begin{array}{l}\text { Earnings } \\
\text { management by } \\
\text { manipulating the } \\
\text { cash flow } \\
\text { statement }\end{array}$ & $\begin{array}{l}\text { Less than six years } \\
\text { From } 6 \text { to } 12 \text { years } \\
\text { More than } 12 \\
\text { years }\end{array}$ & $\begin{array}{l}3.60 \\
3.83 \\
3.30\end{array}$ & - & $\begin{array}{c}0.23 \\
-\end{array}$ & $\begin{array}{l}0.30 \\
0.53 x \\
-\end{array}$ \\
\hline
\end{tabular}

Table (9) shows statistically significant differences at the significance level $(a=0.05)$ in the expected change in earnings management by manipulating the accounts of the financial position in light of the transition to IFRS due to the experience of the accountants, where these differences were in favor of accountants whose experience was six years and more compared to accountants who have experience less than 6 years, the results also indicate that there are differences of statistical significance at the significance level $(a=0.05)$ in the expected change in earnings management by manipulating the cash flow statement in light of the transition to IFRS due to the experience of the accountants, where these differences were in favor of accountants whose experience was more than 12 years compared to accountants who have experience from 6 to 12 years.

The basis on these results, the null hypothesis is accepted that reads: "there are no statistically significant differences at the significance level $(a=0.05)$ in the expected change in earnings management in light of the transition to IFRS (expenses in the income statement, revenue in the income statement, list of equity, earnings management as a whole) due to the experience of the accountants". The null hypothesis is rejected and accepts the alternative assumption which states: "there were statistically significant differences at the significance level of $(a=0.05)$ in the expected change in earnings management in light of the transition to IFRS (the accounts of the financial position, the cash flow statement) due to the experience of the accountants.

\section{Based on the above Results, the ReseARCH ReCOMMENDS THE Following}

1. The necessity of increasing the awareness of the accountants in Saudi joint-stock companies, on the importance of the transition to international financial reporting standards. And to show its positive role in reducing the management of profitability and improve the quality of accounting information. 
2. The necessity for a partnership between the Saudi universities and the Saudi Organization for Certified Public Accountants (SOCPA) and Audit Offices in the Kingdom of Saudi Arabia to study the phenomenon of earnings management and work to limit its existence, and the intimate relationship between reducing them and improving the quality of accounting information through:

a. To organize national and international scientific and international workshops, seminars, and conferences in which universities had hosted by experts from the Saudi Organization for Certified Public Accountants (SOCPA) and experts from the labor market, Audit Offices, and international experts to show the methods of earnings management, how to discover and limit them, and to indicate the minus effects of this phenomenon on business establishments, the national economy, and the quality of accounting information.

b. The Saudi Commission for Certified Public Accountants (SOCPA) in cooperation with universities, auditing offices, and employers on developing an accounting standard dealing with earnings management in companies and the quality of accounting information.

c. To complete the gradual adoption of International Financial Reporting Standards (IFRS) by the Saudi Organization for Certified Public Accountants (SOCPA), and the mandatory application of these standards by companies listed on the Saudi Stock Exchange by the end of the period determined by SOCPA to complete the transition to these international standards.

d. Field training for Saudi university graduates in accounting offices and in companies, through which they learn about the methods of earnings management applied by some companies, how to discover and report on them, and how to improve the quality of accounting information.

e. Urge and encourage Saudi university graduates to obtain a fellowship qualification certificate for Saudi Certified

Public Accountants, enabling them to gain a broad understanding of national and international accounting standards; they can identify and manage ways to earnings management in companies, which increases the quality of accounting information.

f. The continuous rehabilitation and development of corporate accountants in specialized courses in the International Financial Reporting Standards (IFRS) held by the Saudi Universities or the Saudi Organization for Saudi Certified Public Accountants, to show the methods of earnings management, how to discover and limit it, and its relation to the quality of accounting information. g. Developing the national regulations for the ethics of the accounting profession that include the subject of earnings management and the quality of accounting information.

h. The preparation of explanatory leaflets and brochures for business people and investors shows the importance of adopting the International Financial Reporting Standards (IFRS), the risks of earnings management on companies and capital, and the quality of accounting information.

3. The necessity to allocate a semester of courses in the accounting major or to define a path for dealing with profit management and to find the quality of accounting information.

4. The necessity of writing accounting books and carrying out more scientific research to show the risks of earnings management of companies, the importance and maintenance of corporate capital, and how to increase the quality of accounting information.

5. The necessity to form a team of accounting practitioners in companies and audit offices in the Kingdom of Saudi Arabia to study the most common methods of earnings management in companies registered in the Saudi financial market and come up with recommendations on how to reduce this phenomenon.

6. The necessity for government intervention by the financial market of companies and work to find strict laws and legislation that limit the earnings management in companies and work to increase the transparency and quality of accounting information.

\section{References Références Referencias}

1. Abd Elmaula, Nasser Khalifa, and Abo Emara Mustafa (2012), "Assessing the Adequacy of the Current Content of International Financial Reporting Standards in Accounting Programs at Saudi Universities" Research presented to the Financial Reporting Standards Conference (IFRS): Challenges and Opportunities, Faculty of Business and Economics - Qassim University, 1 \& 2 May 2012.

2. Abd Elhafiz, Mohamed Emad, and Ahmed El Zahra Alshahat (2009), "Earnings Management", Research presented to Prof. Dr. Ahmed Foad, Professor of Financial Accounting, Faculty of Commerce - Cairo University, Graduate Studies.

3. Alhalabi L. (2009), "The role of external auditor to reduce the effects of creative accounting on the reliability of financial statements issued by Jordan public shareholding companies", The Middle East University, A Master Thesis in Accounting. 


\section{Second: Foreign References}

4. Ahmed, S. A., M. Neel, and D. Wang (2010), Does Mandatory Adoption of IFRS Improves Accounting Quality? Preliminary Evidence, Working Paper, Texas A \& M University, A New Version (2012) Available at SSRN, http://ssrn.comlabstract $=$ 1502909.

5. Alhalabi L. (2009), "The role of external auditor to reduce the effects of creative accounting on the reliability of financial statements issued by Jordan public shareholding companies", The Middle East University, College of Business, A Master Thesis in Accounting.

6. Cai L. Rahman A., Courtenay S. (2008)" The Effect of IFRS and its Enforcement on Earnings Management: An International Comparison" Electronic copy available at: http://ssrn.com/a bstract $=1473571$.

7. ChangY., Liou C., (2003), "The Effects of IFRS and the Institutional Environment on Accounting Quality in Chinese Listed Firms" The Journal of American Business Review, Cambridge, Vol. 1, Num. 2 pp. 122-128.

8. Chan Y., Cheong C., and Gould G., (2012), "The Impact of Mandatory IFRS Adoption on Accounting Quality: Evidence from Australia" Journal of International Accounting Research, Vol. 11, No. 1, pp. 119-146.

9. Clements, C. E., Neil, J. D., and Stovall, O. S. (2010), "Cultural Diversity, country size, and the IFRS adoption decision", The Journal of Applied Business Research, 26 (2).

10. Daske, H. (2006), Economic benefits of adopting IFRS or US-GAAP Have the expected cost of equity capital really decreased?", Journal of Business Finance and Accounting, 33 (3 \& 4).

11. Firth M. Gounopouios D. and Pulm J. (2013), ÏFRS adoption and Management earnings Forecasts of Australian IPOs" Electronic copy available at: http://sstn.com/abstract=2199034.

12. Goncharov and Zimmermann, (2007), The Mandatory Introduction of IFRS as a Single Accounting Standard in the European Union and the Effects on Earnings Management" For the full text of this master thesis refer to the following webpage: http://hdl.handle.net/2105/5129.

13. Harris, Peter, Ä Case Study: US GAAP Conversion To IFRS With An Analysis on Earninds Management,: Internal Auditing, Jul/Aug 2012, 27, 4.

14. Healy, Paul M, Wahlen, James M., (1999) "A review of the earnings management literature and its implementation for standard settings", Accounting Horizons, 13, 4, Accounting and Tax pg. 365.

15. Karim W., Dunstan K., Nurulhouqe, Zijl T., (2011), "The effect of IFRS Adoption and Investor Protection on Earnings Quality around the World", Electronic copy available at: http://ssrn.com/abstract $=153$ 6460.

16. Kazayuki S. Akinobu S. (2005), Ëarnings Management to Avoid Earnings Decreases and Losses: Empirical Evidence from Japan SSRN: http:??ssrn.com/abstract=701525 or http://dx.dio. org/10.2139/ssrn.701525.

17. Lambert, R., Leuz, C. and Verrecchia, R. E. (2007), Accounting information, disclosure, and cost of capital", Journal of Accounting Research, 45 (2).

18. Leuz, C. (2003), IAS versus US GAAP: Information asymmetry-base evidence from Germany"s new market, Journal of Accounting Research, 41 (3).

19. Leuz C., Nada D., Wysockica P., (2003), Ëarnings management and investor protection: an international comparison", Journal of Financial Economics 69 (2003) 505-527.

20. Leventis S., co-author, (2013), "The impact of IFRS on accounting quality: Evidence from Greece"(Kousenidis), Advances in Accounting, incorporating Advances of International Accounting, 29 (1): 108-123,

21. Liu G., Sun J., (2014), "Did the Mandatory Adoption of IFRS Affect the Earnings Quality of Canadian Firms?" Electronic copy available at: http:// ssrn.com/abstract $=2200735$.

22. Matsuura S., (2008), Ön The Relation Between Real Earnings Management and Accounting Earnings Management: Income Smoothing Oerspective", Journal of International Business Research, Volume 7, Special Issue 3, 2008.

23. Parbonetti E., (2011), "Mandatory IFRS adoption: the trade-off between accrual and real-based earnings management", Electronic copy available at: http://ssrn.com/abstract $=2039711$.

24. Patricia M., Dechow D., Skinner J., (2000), Ëarnings Management: Reconciling the Views of Accounting Academics, Practitioners, and Regulators", c 2000 American Accounting Association Accounting Horizons Vol. 14, No. pp235-250.

25. Peng, S. and J. Smith (2010), "Chinese GAAP and IFRS: an analysis of the onvergence process", The International Journal of Accounting, Auditing and Taxation, 19 (1): 16-34.

26. Schilit H., (2002), "Review: Financial Shenanigans: How to Detect Accounting Gimmicks and Fraud in Financial Reports"books.google.com.sa/books?isb $\mathrm{n}=0071386262$

27. Stergios Leventis et. Al., "Loan Loss Provisions, Earnings Management and Capital Management under IFRS: The Case of EU Commercial Banks", J. Finance Serve Res (2011) 40.

28. Steven M. Mintz, (2010), implementation Cencerns about IFRS Adoption in the US", Journal of International Business Education, Volume 5: 2010, pp. 97-116. 
29. Verdan Capkun, Daniel W. Collins and Thomas Jeanjean, "Does Adoption of IFRS Deter Earnings Management?", Electronic copy available at: http://ssrn.com/abstract $=1850228$, Version of 22-12.

30. Ying Wang and Michael Compbell, (2012), Earnings Management Comparison: IFRS vs. China GAAP", International Management Review, Vol. 8 No. 1.

31. Wagenhofer A., Ewera R., (2005), Economic Effects of tightening Accounting standards to restrict earnings management", The Accounting Review, Vol. 80, Vo. 4. Pp. 101-124. 